\title{
The Analysis of Integration between Hijab Concept and Fashion in Indonesia
}

\author{
Citra Puspitasari ${ }^{1}$ \\ Textile and Fashion Department, School of Creative Industries, \\ Telkom University, Bandung, Indonesia. \\ citrapuspitasari@telkomuniversity.ac.id
}

\author{
Jasni Dolah ${ }^{2}$ \\ Department of New Media, School of the Arts, \\ Universiti Sains Malaysia, Pulau Pinang, Malaysia. \\ jasnidolah@usm.my
}

\begin{abstract}
Wearing a Hijab is both a religious and cultural practice for Muslim women performed to express their identity and spiritual faith. Muslim women or Muslimah in Indonesia increasingly wearing the Hijab. Hijab as an expression of cultural identity and communication, its main message is in addition to carry out their religious orders and can also look fashionable. For the example, in the social media, there are various images in which the Hijab presented as a form of fashionable accessories and it is adapted to various modern outfit. The fact how Hijab and fashion develop in Indonesia until today is quite different from a few years ago. Therefore, it is interesting to know how the Hijab and fashion in Indonesia are integrated and evolved to this day. The methods which will apply in this study consist of literature review, direct observation and interview. From this study, there will be obtained how Hijab and fashion concept can be integrated in Indonesia.
\end{abstract}

Keywords : Hijab, Fashion Design, Muslim Fashion, Communication.

\section{INTRODUCTION}

Hijab comes from Arabic word hajaban that means cover or a thing which covering something (else). Hijab can be sort of cloth or other material that covers a room (curtain), but it can be also a material to cover a wall in what-so-ever to hinder it. In some countries which use Arabic as a language, also in several west nations, hijab is well-known refers to veil which is worn by Muslim woman [1]. The veil itself in the Al-Qur'an means the cloth that covers woman's head extended far enough to the breast part [2]. In Indonesia, the term of veil which is generally in previous time the people used to wear is long-shawl, but today the term has a kind of deduction of meaning with the name: hijab [2]. Because of that, this research, the range of the term hijab is confined to the cover of the head for the Muslim women only.

The wearer of hijab in Indonesia had a significant increase which is proven by the getting-more preferred of it by the young women and also the teenagers as one of the reasons [3]. This circumstance is different from the previous era where the hijab wearer was dominated by the adults.

Hijab develops as an important thing for most of women and it also can satisfy the consumerism soul of them. The shape and style of hijab which appeared not rarely ignored the value and function of the hijab in Islam as a cover of Muslim women aurat in order to prevent themselves from male whose not their mahram when they were in the public areas. Hijab is now a symbol that is not simply to value or function but also used as a charm or allure for most of Muslim women [4].

Based on the statements above, the problem is, because of the style and form of Hijab in Indonesia nowadays, the value and function of Hijab often became changing. Nevertheless, the wearer of hijab in Indonesia had a significant increase. It was interesting to be discussed, especially about how it can be occurred. The discussion focused on the Muslim fashion designer's role as a part of Muslim fashion industries in Indonesia.

\section{LITERATURE REVIEW}

\section{A. THE BASIC CONCEPT OF HIJAB}

There are some points which declared as the basic rule in Islam of how Muslim wear the clothing to cover their aurat [5]. The following are three of ten points which pertain to hijab. First requirement is covering the genitals. According to al-qur'an Chapter 24 (an-nur): verse 31, it was explained that a muslim woman (Muslimah) should close the entire parts of the body except the part which usually appears. This verse is related to genitals' limitation that a muslimah has. The Islamic scholars agreed that genitals's limitation of muslimah is entire parts of the body except face and palm. Second is clothes are not decoration. A muslimah is forbidden to wear clothes which is too groom herself. Then, the third is, the clothes should not be glaring whether in the motive or the colour. The glaring clothes here mean being the public's attention.

Rasululullah prohibits the people wear 'syuhrah' clothes [5]. These clothes are the clothes that is meant to be cynosure, good that is luxurious clothes so that it can make people being proud but also wear ugly clothes and limp so that assumed zuhud.

\section{B. MUSLIM FASHION AS COMMUNICATION}

According to the statement of Barnard (2011) that fashion is a form of communication, wearing the hijab in the context as part of a Muslim community have an important meaning. Hijab is not just as a cover of the aurat, but also as a form of message with various meanings in it [6]. As for the multiple meanings in general, hijab can be identified into three things, namely; as a manifestation of religious ideology, as a symbol of community and affiliation as attributes that describe the social status [7].

\section{HIJAB FASHION IN INDONESIA}

Nowadays the trend of Hijab fashion this time is experiencing significant development. This is caused by several things, some of them are technology and information progress, the popularity of religious proselytizing communities, and the events of Muslim fashion fairs. In addition, realisation of the trends which was combined with the cultural elements made the Muslim fashion looked more dynamic, including Hijab fashion in 
it. This encourages the Muslim fashion designers to innovate more than before.

Therefore, Indonesia proclaimed to become the qibla of world's Muslim fashion in 2020. It was stated by the government of Indonesia and Indonesia Islamic Fashion Consortium (IIFC) [3].

1990s era became the period of the transpiring of Hijab Revolution 1.0, where the previous condition was the very limited wearer of hijab and then it was finally change to be an allowance. It triggered the freedom of wearing hijab widely in the society of people. The freedom of wearing hijab was felt by the people so at the end it became the impeller of the growth of Muslim fashion in Indonesia [8].

The next era 2010s, occurs the Hijab Revolution 2.0 where hijab has really become the lifestyle of the people. Hijab is not only the symbol of obedience to the rule of the religion, but rather as an expression of lifestyle also [8]. As a property of social, the meaning of hijab depends on where a woman lives, their context, and how they tried to define themselves. The existence of Hijab Revolution 2.0 is triggered by the raise of Muslim fashion designer in Indonesia who takes place to impel the image of hijab to the international level [8].

The deduction-movement of term veil becomes hijab in Indonesia starts to be sensed in this era. Besides, at the time of Hijab Revolution 2.0 era, the manner of the hijab is appeared more fashionable, modern, and stylish as the form of acculturation combination between Islam and modernity [9]. That kind of appearance has the effects and one of them is the rapid of the development Indonesia Muslim fashion globally.

\section{THE PROCESS OF SOCIAL INTEGRATION}

Social integration is a process that happens gradually. The process can be started from the accommodation wishes of various parties to work together. Then it was continued with various forms of cooperation. In the process, each party trying to overcome differences and accommodate the desires, expectations or needs with each other. Furthermore, each party sought to heighten the unity of action and attitude to a common goal [9].

\section{METHODOLOGY}

The method that is used in this research is qualitative method with primary and secondary data collecting method as follows:

\section{a. Primary Data}

Observation including direct and indirect. Direct observation by visiting several Muslim fashion shows. The purpose is to detect how hijab fashion trend that is blooming to be socialized at the moment. Indirect observation by browsing the internet. Its aim is doing the detection by detail with hijab fashion design that is made by several designer whose took a part in Muslim Fashion Association.

Interviewing several informants with the various purpose. Its aim is, on of amongst, to detects the causation of its blooming clothing's user syar'i, detect boundaries in fashion in islam by confirming explanation the conception of modern syar'i clothing.

\section{b. Secondary Data}

The data gained from related sources from books, journals, internet will be used as additional references and to gain knowledge and informaation. To complete the study references, source from magazine, newspaper, video report and television program will also be used to update information in the area of research.

\section{RESULTS AND DISCUSSION}

Indonesia has the largest of Muslim population in the world. The influence of Islam implemented on various aspects of life including the prevailing values of society. The influx of Fashion items on the Hijab led to the development of the meaning of Hijab itself. Although there was an increase in interest of hijab wearing in the Muslim society in Indonesia, but criticism about its development especially in the meaning and purpose of hijab wearing was voiced by various parties. In Indonesia, the term of hijab originally known as the veil and this term began to be common and often used by one of Muslim women community in Indonesia, i.e. Hijabers Community (HC) in 2011. The fashionable hijab styles were introduced and developed by HC. According to their opinion, fashion things in hijab permitted as long as it closes the nakedness and do not show the shape of body [10].

Hijab Fashion for HC can be used as a tool for syi'ar by making the visual look of hijab became more beautiful and stylish. So that, it will encourage more Muslim women to be interested in wearing the hijab. The efforts to make hijab look more beautiful contrary with the basic purpose of wearing the hijab itself. Referring to the historical development of the use of hijab in Indonesia, there are some stages. First, it was started with the restricted of the use of hijab before 1990s. Then, in 1991 the Government of Indonesia issued a decree No. 100 which allows the use of hijab in every educational institution [11]. Since then, the rate of Muslim women who wore the hijab was increased and it was not only in the Education sector, but also the Muslim women in another sector included the celebrities. Since then, the rate of Muslim women who wore the hijab was increased and it was not only in the Education sector, but also the Muslim women in another sector included the celebrities. The presence of artists and celebrities who wore the hijab influenced the community on how to get dressed. Later, in the 2000s, hijab became a trend and new sector in economy. This trend gave rise a conflict on how we put the positioning of hijab. It was divided into two groups, first group eager to return to Islam and the second group was the thesis of the first group. The second group treated the hijab as a form of expression for Muslimah to be look trendy and fashionable meanwhile at the same time they fulfill religious orders [11].

As for the multiple meanings in general, hijab can be identified into three things, namely; as a manifestation of religious ideology, as a symbol of community and affiliation as attributes that describe the social status [7]. Hijab is considered as a great tradition in Islam, but more than that, hijab serves as a means of communication that conveys the messages of social and culture. Tradition of wearing the hijab was originally an affirmation over the identity of the diversity. In its development, the definition of the hijab was experiencing a significant shift. Hijab is no longer functioning as a religious symbol, but it has entered the realm of the cultural sphere-, social, political, economic and also fashion.

Basically, fashion is a complex thing, but it can be understood as shifting styles of dress-that is, specific combination of silhouettes, textiles, colors, details and fabrications-embraced by groups of people at a particular 
time and place [12]. Hijab that currently goes into the realm of fashion have varied views. The conception of the hijab which accordance with the rules of Islam and the conception to be fashionable when wearing the hijab, started to be put together. Muslim fashion designer was instrumental in bringing together the two things [8]. The efforts being made to minimize the conflict between these two concepts was by integration. Integration refers to the adjustment or the melting of two or more different things to be merged [9]. Stages of the integration process began with the stage of accommodation which is the efforts made on the basis of the desire of both parties to work together. Appearing wellgroomed and neat, presenting a pleasant, harmonious look is recommended in Islam and it may also be considered a form of visual da'wa [13]. The role of a Muslim fashion designer in fashion hijab as visual displays of da'wa is getting noticeably since the revolution Hijab 2.0 started in the era of 2010an [8].

Muslim fashion designers in Indonesia took a part as an agent of change in the development of hijab fashion. Through their hijab design collection, they showed the values which they believe. It was inseparable from the existence of various activities of Islamic studies in society that affect the viewpoints in wearing the hijab. Social media-based on videos, pictures and writing became the intermediaries tools to spread various Islamic knowledge. The existence of two opposing groups in viewpoints towards hijab, gave rise to a variety of studies about hijab itself. Islamic scholars through the Islamic study groups explained the various scientific Islamic knowledge such as tawheed and fiqh, including discussed about how to dress. After received the explanation from Islamic scholars about Islamic knowledge, the quick response of the Muslim community were different, it depend on their choosing. One of the most visibly was the visual appearance. Clothing became one of the communication tools which represented the ideology, affiliation to a particular community or a viewpoints and also social class.

As an attempt to classify how to dress and wearing the hijab, it was concluded by Indonesia Trend Forecast Association - BEKRAF, there were two major groups, namely the Syar' $i$ and Modest [15].

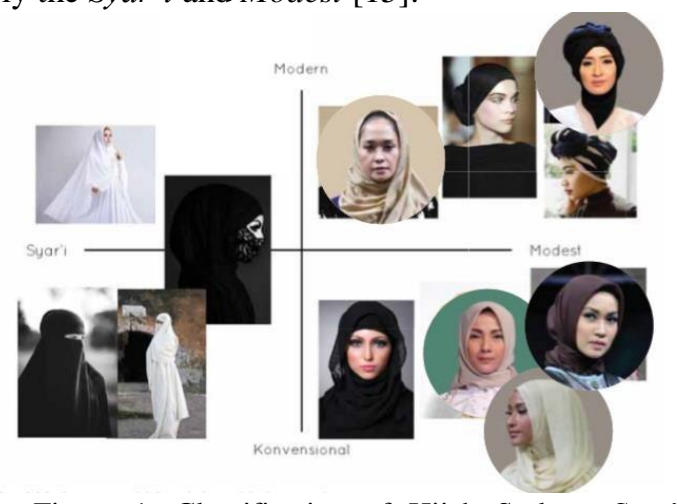

Figure 1. Classification of Hijab Style - Syar'I \& Modest

Syar' $i$ was a style with a religious approach and in Indonesia, this kind of style became something new. Modest style has long been used in Indonesia. Its approach was more functional. Based on this classification, there will be direction for Muslim fashion designer in designing the hijab.
The essential thing to fashion design is the duality of solving functional problems and improving the look or feel of the product through style, decoration, and embellishment [16]. In Syar'I style, there was an effort to combine it with fashion design concept through the visual appearance of the product.

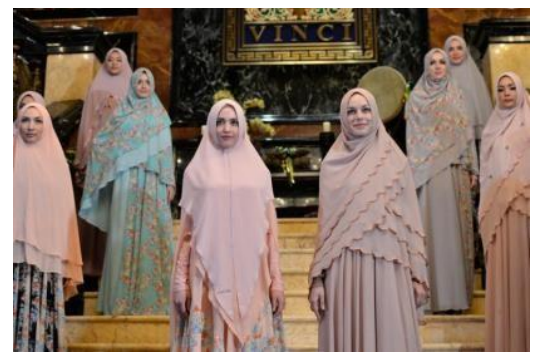

Figure 2. Syar'I Style by SiSeSa Brand

For the example, SiSeSa, one of the famous hijab fashion Syar'I applied the surface decoration such as fabric layering and beads in the bottom part of hijab. Color combination is also the subject of consideration in the design of hijab. SiSeSa used the pastel color palletes in their collection. It was chosen because of consumer preferences and part of their concept as a Syar'I hijab fashion brand.

In addition to the efforts made by a muslim fashion designer, brand make up also have contributed in encouraging the development of hijab fashion [7]. Wardah succeed in shifting the stigma of hijab, which formerly was associated as being identical to the participants of the traditional Islamic study group and clothes which outdated, into something that a part of the lifestyle. Hijab is not just as a symbol of obedience to religion but rather an expression of lifestyle.

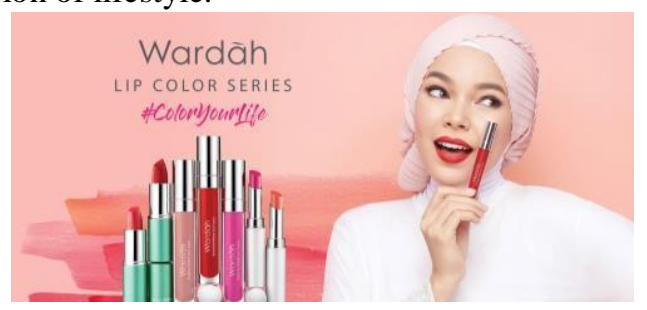

Figure 3 .

Artists and celebrities who wear the hijab became one of the role models in hijab fashion. Wardah as one of the make up brand which targeting Muslim segment, embrace the artists and celebrities who wear the hijab to be their brand ambassador. It effectively lifted the stigma of hijab into something popular and trendy. Celebrities who partnered by Wardah besides the artists and models, including some of them were Muslim fashion designers. Those Muslim fashion designers were the influencers that are also part of the Hijabers Community (HC). The interaction which created was the mutual interaction for each other. Wardah became a supporter of the fashion event, especially as a sponsor for the official make up, whereas Muslim fashion designers participated and customize their design collection with the product of Wardah.

\section{CONCLUSIONS}

Based on the previous description, it can be concluded into some points: 
1. Hijab fashion is a part of the culture in Indonesia which existed in daily life.

2. Hijab as a part of the Muslim community life in Indonesia are experiencing a shift in functions and values. It didn't always mean negative because there were many aspects and reasons such as the improvement of technology, economic condition, social and culture in society, which encouraged why it can be happened

3. In order to facilitate different groups of muslim societies, the design and style of Hijab became varies. There were Syar'i style and Modest style.

4. The Muslim fashion designer and brand make up have great influence in integration process between hijab concept and fashion.

5. Wardah as the local maked up brand consistently showed courteous impression through hijab and fashion in its advertisement.

\section{REFERENCES}

[1] Y. N. Triyana, "Hijab for brain, beauty and behavior", Yogyakarta: Sabil (Laksana Group), 2017.

[2] E. Zami, A - Z Hijab, Jakarta: Pustaka Oasis, 2014.

[3] Republic of Indonesia, Ministry of Trade, Warta Ekspor. Jakarta: Ditjen PEN/WRT/31/IV/2015 April Edition.

[4] G. Sukendro, A. H. Destiarman, K. Kahdar, "Commodity Fetishim Values of Hijab Style (Headscarf And Veil) in Muslimah Wear", Jurnal Sosioteknologi, Vol. 15 No. 2, 2016, pp. $241-254$.

[5] M. N. Albani, "Jilbab wanita muslimah menurut Qur'an dan Sunnah”. Surakarta: At-Tibyan, 2011

[6] M. Barnard, "Fashion sebagai Komunikasi Cara Mengkomunikasikan Identitas Sosial, Seksual, Kelas dan Gender", Yogyakarta: Jalasutra, 2011.

[7] K. Yuswohady, I. Herdiansyah, F. Fatahillah and H. Ali, "Gen M: Generation Muslim”, Yogyakarta: Bentang Pustaka, 2017.

[8] M. Fakhruroji, U. Rojiati, "Religiously Fashionable: Constructing Identity of Urban Muslimah in Indonesia", Jurnal Komunikasi Malaysian Journal of Communication Jilid 33(1) 2017, pp. 199-211.

[9] Koentjaraningrat, "Masalah Kesukubangsaan dan Integrasi Nasional”. Jakarta: Universitas Indonesia, 1993.

[10] A.A. Nursyahbani, "Konstruksi dan Representasi Gaya Hidup Muslimah Perkotaan", Thesis. Jakarta: Universitas Indonesia, 2012.

[11] Dadi Ahmadi, Nova Yohana, "Konstruksi Jilbab sebagai Simbol Keislaman”, Mediator, Vol. 8 No. 2, 2007, pp. 236248.

[12] A. Kennedy, E. B. Stoehrer \& J. Calderin, "'"Fashion Design Referenced: A Visual Guide to the History, Language, \& Practice of Fashion”, Beverli, MA: Rockport Publisher, 2013.

[13] R. Arzu Ünal, Annelies Moors, "Formats, fabrics, and fashions:

Muslim Headscarves Revisited", The Journal of Art, Objects and Belief, 2012, Material Religion, 8:3, 308-329

[14] Fadila Grine, Munazza Saeed,"Is Hijab a fashion statement? A study of Malaysian Muslim women", Journal of Islamic Marketing, Vol. 8 Issue: 3, 2017, pp.430-443.

[15] Indonesia Trend Forecast, "Modest Fashion - Greyzone Trend Forecasting 2017-2018", Jakarta: BEKRAF, 2016.
[16] J. Wiley and Sons, "Fashion - Philosophy for Everyone: Thinking with Style", West Sussex: Blackwell Publishing Ltd., 2011 